\title{
A critical study on Various Frameworks used to analyse International Business and its Environment
}

\author{
P. S. Aithal \\ Srinivas Institute of Management Studies, Srinivas University, Mangalore - 575 001, INDIA. \\ E-Mail: psaithal@gmail.com
}

Type of the Paper: Research Paper.

Type of Review: Peer Reviewed.

Indexed In: OpenAIRE.

DOI: http://dx.doi.org/10.5281/zenodo.1053578.

Google Scholar Citation: IJAEML

\section{How to Cite this Paper:}

Aithal, P. S. (2017). A critical study on Various Frameworks used to analyse International Business and its Environment. International Journal of Applied Engineering and Management Letters (IJAEML), 1(2), 78-97.

DOI: http://dx.doi.org/10.5281/zenodo.1053578.

International Journal of Applied Engineering and Management Letters (IJAEML)

A Refereed International Journal of Srinivas University, India.

(c) With Authors.

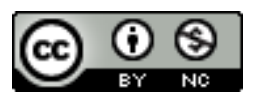

This work is licensed under a Creative Commons Attribution-Non Commercial 4.0 International License subject to proper citation to the publication source of the work.

Disclaimer: The scholarly papers as reviewed and published by the Srinivas Publications (S.P.), India are the views and opinions of their respective authors and are not the views or opinions of the S.P. The S.P. disclaims of any harm or loss caused due to the published content to any party. 


\title{
A critical study on Various Frameworks used to analyse International Business and its Environment
}

\author{
P. S. Aithal \\ Srinivas Institute of Management Studies, Srinivas University, Mangalore - 575 001, INDIA. \\ E-Mail: psaithal@gmail.com
}

\begin{abstract}
The objective of any business organization is profit and sustainability. To attain this objective majority of business organizations follow a strategy to identify and encash all possible opportunities which include low-cost, product differentiation, high-tech products \& services, international expansion, continuous value addition to products \& services, and so on. As a result, many business organizations started in a given country, expanded their business to almost entire world and became global players. Such expansion strategy transformed them into multinational business firms having a number of subsidiaries or branches and through their huge structure, market share, and capability, and hence they became a prominent player in their industry/industry sector. Some of such firms further expanded their business to different industry and industry sectors and also started to use many business models to reach and cover the entire world. In this paper, we have discussed various business analysing frameworks used to analyse the business system and strategy used by many international firms and the environmental factors affecting their business. We have used ABCD listing methodology to identify the advantages, benefits, constraints, and disadvantages of these identified frameworks to analyse international business strategies and environmental analysis frameworks. Both criticism and suggestions on available framework usage are also given.
\end{abstract}

Keywords: Frameworks used to analyse international business, ABCD listing on International business frameworks, Business analysing frameworks.

\section{INTRODUCTION :}

Doing anything with profit motivation can be considered as business. The objective of any business organization is profit and sustainability. To attain this objective majority of business organizations follow a strategy to identify and encash all possible opportunities which include low-cost, product differentiation, high-tech products \& services, international expansion, continuous value addition to products \& services, and so on. As a result, many business organizations started in a given country, expanded their business to almost entire world and became global players. Such expansion strategy transformed them into multinational business firms having a number of subsidiaries or branches and through their huge structure, market share, and capability, and hence they became a prominent player in their industry/ industry sector [1-5]. Some of such firms further expanded their business to different industry and industry sectors and also started to use many business models to reach and cover the entire world. International business got boosted after the process so-called Globalization which supports an integrated and interdependent global economy due to the globalization of production and globalization of markets. The globalization of production includes the use of goods and services from different locations in the world to take advantage of national differences in terms of quality and cost of production factors such as labour, technology, energy, land, and capital. This decreases their overall cost of production and improve the quality or features of their product/service offering, and hence allowing them to compete more efficiently and effectively.

The globalization of markets leads to merger of many national markets into large one global marketplace. Many countries decision on decreasing trade barriers for cross-border business have 
made it easier to sell internationally. Due to the enhanced exchange of information and human beings between countries, it is believed that the tastes, preferences, and buying habits of people in different countries are started to converge on some global standards, leading to the creation of global market. Still, significant differences exist between different national markets along with many relevant aspects like consumer tastes and preferences, distribution channels, culturally embedded value systems, traditional views, and so on. Solving such differences need focus on marketing strategies, operating practices and product features be customized to optimum levels in a country. Two macro factors considered as drivers of globalization seem to accelerate the trend toward greater globalization. They are (1) Declining Trade and Investment Barriers - the decline in barriers to the free transfer of goods, capital and services that have occurred since the beginning of $20^{\text {th }}$ century. (2) The Role of Technological Change - particularly the dramatic developments in communication, information processing, internet, and transportation technologies in recent years.

The international business is being a positive sum game, where all the participant countries or firms are going to get benefits and hence this model of doing business by improving the modalities of it and decreasing the constraints of it became the prior policy of many country governments. In order to support cross-country business by the country governments have developed many strategies and created many policies to boost the focus on international business through all possible modes of entry. But the multinational organizations which have objective of making enhanced profit through expanding their business to many countries with the intention to gain through globalized market to their products/services or through globalized production to take advantage of low cost, quality resources availability and hence to become low cost players. Any firm which has plans to go for international investment for production or marketing studies the environmental factors of that business both at home country and host country. Environmental diagnosis consists of managerial decisions made by analyzing the significance of the data (opportunities and threats) of the environmental analysisll. It is quite obvious that environmental analysis is the cornerstone of new business opportunity analysis too. Indeed, today a much greater emphasis is given than in the past to the fact that environmental analysis is an essential prerequisite for strategic management decision-making [15]. The some of the major external environmental factors which effects in international business decisions are:

(a) Economic Environment

(b) Political Environment

(c) Socio-cultural Environment

(d) Technological Environment

(e) Legal environment

\section{OBJECTIVE OF PRESENT STUDY :}

In this paper, we have discussed various business analysing frameworks used to analyse the business system and strategy used by many international firms and the environmental factors affecting their business with the following intention :

(1) To have an insight into major environmental factors which affects the international business decisions of a firm.

(2) To know various frameworks used to analyse International business Decisions of a firm based on its internal and external environments. This includes studying its operational environment, business environment, and corporate environment.

(3) To study the important, identified frameworks/techniques in terms of their discussion parameters, various variables used in the analysis, determinant issues, and implications on decisions related to new investments and continuing the existing business in different countries.

(4) To use SWOC framework identify the strength, weakness, opportunities, and challenges of a firm in its international business objectives.

(5) To use ABCD listing methodology to identify the advantages, benefits, constraints, and disadvantages of these identified frameworks to analyse international business strategies and environmental analysis frameworks. 


\section{VARIOUS FRAMEWORKS USED TO ANALYSE BUSINESS SYSTEMS :}

Various frameworks are used to analyze individual characteristics or organizational effectiveness \& strategies in a given environment. Such frameworks make use of some of the identified but important parameters as per the objective of the analysis to determine certain characteristics of the model under investigation. Such parameters allow the researchers to study a given model/system in-depth to know the identified properties from various internal and external frame of references. Many frameworks are developed and used to analyse systems/models which include SWOC analysis, PESTLE analysis, McKinsey 7S framework, ICDT model, Portor's five force model, ABCD listing technique etc. Out of such frameworks used for business model /system analysis, some popular frameworks such as SWOC (strengths, weaknesses, opportunities, and challenges), PESTEL (Political, Economic, Socio-cultural, Technological, Environmental, and Legal), and ABCD (Advantages, Benefits, Constraints, and Disadvantages) are applicable to all kind of business and its internal and external environmental situations. Other frameworks such as Porter's Value Chain Analysis (VCA), facilitate the analysis of processes within a company but do not provide an easy mechanism to link these to high-level business objectives, relationships, and the underlying economic logic of a business enterprise. A consistent method to analyze the structure, behaviour and the dynamics of a firms business should allow to identify the possible optimizations governing the business models, to assess the impact of innovative changes and to identify critical success factors before the changes are implemented within a particular environment. The following table 1 lists various frameworks used in analysing a business model or system along with their inventors and the focuses on such analysis process [6].

Table 1 : Various frameworks used in firms for business model analysis along with their inventors and focuses on analysis [6].

\begin{tabular}{|l|l|l|l|}
\hline S. No. & Analysis Framework & Inventor & Focus \\
\hline 1 & $\begin{array}{l}\text { SWOT/SWOC analysis } \\
\text { [7] }\end{array}$ & $\begin{array}{l}\text { Albert Humphrey at the } \\
\text { Stanford Research Institute } \\
\text { during 1960. }\end{array}$ & $\begin{array}{l}\text { Strength, Weakness, } \\
\text { Opportunities, and } \\
\text { Threats/Challenges. }\end{array}$ \\
\hline 2 & $\begin{array}{l}\text { PEST/PESTEL } \\
\text { analysis [8] }\end{array}$ & $\begin{array}{l}\text { Francis Aguilar at Harvard } \\
\text { Business School during 1967. }\end{array}$ & $\begin{array}{l}\text { Political, Economic, Sociological, } \\
\text { Technological, Legal, \& } \\
\text { Environmental analysis. }\end{array}$ \\
\hline 3 & $\begin{array}{l}\text { Six thinking hat } \\
\text { analysis [9] }\end{array}$ & Edward de Bono during 1985. & $\begin{array}{l}\text { Managing Blue, } \\
\text { Information White, } \\
\text { Emotions Red, } \\
\text { Discernment Black, Optimistic } \\
\text { response Yellow, } \\
\text { Creativity Green. }\end{array}$ \\
\hline 4 & $\begin{array}{l}\text { McKinsey 7-S } \\
\text { framework [10] }\end{array}$ & $\begin{array}{l}\text { Robert H. Waterman, } \\
\text { Jr. and Tom Peters of } \\
\text { McKinsey \& Company } \\
\text { consulting firm in the 1980s. }\end{array}$ & $\begin{array}{l}\text { Strategy, Structure, system, } \\
\text { Shared values, Skills, Style, and } \\
\text { Staff. }\end{array}$ \\
\hline 5 & $\begin{array}{l}\text { Balanced scorecard } \\
\text { [11] }\end{array}$ & $\begin{array}{l}\text { Analog Devices in 1987. The } \\
\text { framework is popularized by } \\
\text { Dr. Robert Kaplan and David } \\
\text { Norton in the early 1990s. }\end{array}$ & $\begin{array}{l}\text { A management technique } \\
\text { designed to provide a view of an } \\
\text { organization from both internal } \\
\text { and external perspective. }\end{array}$ \\
\hline 6 & $\begin{array}{l}\text { Michael E. Porter of Harvard } \\
\text { Business School during 1979. }\end{array}$ & $\begin{array}{l}\text { Five competitive forces on } \\
\text { business performance including } \\
\text { threat of new entrants, threat of } \\
\text { substitutes, bargaining power of } \\
\text { customers, bargaining power of } \\
\text { suppliers, and industry rivalry. }\end{array}$ \\
\hline \hline
\end{tabular}




\begin{tabular}{|c|c|c|c|}
\hline & matrix [13] & $\begin{array}{l}\text { developed by Bruce D. } \\
\text { Henderson for the Boston } \\
\text { Consulting Group in } 1970 .\end{array}$ & $\begin{array}{l}\text { products) on the basis of their } \\
\text { relative market shares and growth } \\
\text { rates into four categories as Cash } \\
\text { cows, Dogs, Question marks, and } \\
\text { Stars. }\end{array}$ \\
\hline 8 & $\begin{array}{l}\text { Value Chain analysis } \\
\text { [14] }\end{array}$ & $\begin{array}{l}\text { Michael E Porter of Harvard } \\
\text { Business School during } 1985 .\end{array}$ & Primary and Support activities. \\
\hline 9 & Delta Model [15] & $\begin{array}{l}\text { Dean Wilde and Arnoldo C. } \\
\text { Hax at MIT during } 2003 .\end{array}$ & $\begin{array}{l}\text { Total customer solution, System } \\
\text { lock-in, Best product. }\end{array}$ \\
\hline 10 & $\begin{array}{l}\text { Resource Based View } \\
\text { Analysis [16] }\end{array}$ & $\begin{array}{l}\text { Barney, Jay B. Texas A\&M } \\
\text { University, during } 1991 .\end{array}$ & $\begin{array}{l}\text { Tangible resources, Intangible } \\
\text { resources, and organizational } \\
\text { capabilities. }\end{array}$ \\
\hline 11 & $\begin{array}{l}\text { Core competency } \\
\text { analysis [17] }\end{array}$ & $\begin{array}{l}\text { C. K. Prahalad and Gary } \\
\text { Hamel of University of } \\
\text { Michigan during } 1990 .\end{array}$ & $\begin{array}{l}\text { Organization's collective } \\
\text { learning, particularly of how to } \\
\text { coordinate diverse production } \\
\text { skills and integrate multiple } \\
\text { technologies. }\end{array}$ \\
\hline 12 & $\begin{array}{l}\text { Heptalysis } \\
\text { Analysis [18] }\end{array}$ & Pejman Makhfi during 2005. & $\begin{array}{l}\text { Market opportunity, } \\
\text { Product/solution, } \\
\text { Execution plan, } \\
\text { Financial engine, } \\
\text { Human capital, } \\
\text { Potential return, and } \\
\text { Margin of safety. }\end{array}$ \\
\hline 13 & $\begin{array}{l}\text { MOST /VMOST } \\
\text { analysis [19] }\end{array}$ & $\begin{array}{l}\text { Rakesh K. Sondhi, BMC } \\
\text { Global Services Ltd. U.K., in } \\
1999 .\end{array}$ & $\begin{array}{l}\text { Vision/Mission, Objectives, } \\
\text { Strategies, and Tactical. }\end{array}$ \\
\hline 14 & $\begin{array}{l}\text { CATWOE analysis } \\
\text { [20] }\end{array}$ & $\begin{array}{l}\text { David Smyth, and Peter } \\
\text { Checkland of University of } \\
\text { Lancaster, England in } 1975 .\end{array}$ & $\begin{array}{l}\text { Customers, Actors, } \\
\text { Transformation process, World } \\
\text { view, Owner, Environmental } \\
\text { constraints. }\end{array}$ \\
\hline 15 & VPEC-T analysis [21] & $\begin{array}{l}\text { David Hunt, \& Liz Bacon, } \\
\text { Computing and Mathematical } \\
\text { Sciences Department, } \\
\text { University of Greenwich, } \\
\text { during 2009. }\end{array}$ & $\begin{array}{l}\text { Values, Policies, Events, Content, } \\
\text { and Trust. }\end{array}$ \\
\hline 16 & $\begin{array}{l}\text { ICDT Model for E- } \\
\text { business [22] }\end{array}$ & $\begin{array}{l}\text { Developed by Albert } \\
\text { Angehrn at INSEAD, France } \\
\text { in } 1997 .\end{array}$ & $\begin{array}{l}\text { Segmentation of the virtual } \\
\text { 'market-space' into four distinct } \\
\text { areas: Information Space, } \\
\text { Communication Space, } \\
\text { Distribution Space, \& } \\
\text { Transaction Space. }\end{array}$ \\
\hline 17 & ABCD Analysis [23] & $\begin{array}{l}\text { Aithal P. S. et al. of SIMS, } \\
\text { India in } 2015 .\end{array}$ & $\begin{array}{l}\text { Affecting Factors and Constituent } \\
\text { critical elements based on Key } \\
\text { attributes of various Determinant } \\
\text { issues of a concept, business } \\
\text { model, strategy, or a system, } \\
\text { under four constructs named as } \\
\text { Advantages, Benefits, } \\
\text { Constraints, and Disadvantages. }\end{array}$ \\
\hline
\end{tabular}




\section{VARIOUS FRAMEWORKS USED TO ANALYSE INTERNATIONAL BUSINESS OPPORTUNITIES :}

In international business decisions, a multinational country should analyse its internal capabilities of performance in terms of developing unique or differentiated products or services through its ability of research \& innovation, better production processes, lower production cost, lower wastage, better marketing strategies, and appreciable after sales support. The external opportunities can be analysed through environmental analysis which is defined as the process by which the decision makers monitor the economic, governmental, legal, market, competition, supplier, technological, geographic, and social settings to determine opportunities and challenges to their firms. In the context of international business decisions, the environmental diagnosis consists of managerial decisions made by analyzing the significance of the data on opportunities and challenges of the environmental analysis. It is, however, quite obvious that environmental analysis is the cornerstone of international business decisions due to the fact that such decisions consume a lot of time and energy of top executives along with a large amount of financial investment. Indeed, in international business expansion decisions today a much greater emphasis is given than in the past to the fact that environmental analysis is an essential prerequisite for strategic management decision-making. To know internal capabilities of performance of a multinational firm in terms of developing unique or differentiated products or services, an analysis of the strengths, weaknesses, opportunities, and challenges (SWOC) is essential for deciding on international investment for production and marketing. Just as the life and success of an individual depend on his innate capability, including physiological factors, traits and skills, to cope with the environment, the survival and success of a business firm depend on its innate strength - the resources as it command, including physical resources, financial resources, skill and organization and its adaptability to the ever changing environment. Every business enterprise, thus, consists of a set of internal factors and is confronted with a set of external factors. The internal factors are usually considered as controllable factors because the enterprise has control over such factors and can alter or modify them as its human resources, physical facilities, organization and functional means, such as the marketing mix, to suit the environmental demand. The external factors, on the other hand, are by and large, beyond the control of a company. The external or environmental factors such as the economic factors, socio-cultural factors, government and legal factors, demographic factors, geophysical factors etc. are, therefore, generally regarded as uncontrollable factors. As the environmental factors related to international decisions are beyond the control of a firm, its success will depend to a very large extent on its adaptability to the business environment, i.e. its ability to properly design and adjust the internal (the controllable) variables to take advantage of the opportunities and to combat the challenges in the environment. The business environment comprises a micro-environment and a macro environment. The micro-environment deals with mainly the stakeholders of the multinational company include the suppliers, marketing intermediaries, competitors, customers, and public people. The macroenvironment consists of the larger societal forces that affect all the stakeholders in the company's micro-environment namely, the demographic, economic, natural, technological, political and cultural forces of the country where the multinational company is intended to invest. Out of many frameworks used for international business environmental analysis, some popular frameworks are SWOC (strengths, weaknesses, opportunities, and challenges), balanced scorecard, PESTEL, Porter's Value Chain Analysis (VCA), are used extensively. Recently introduced analysis framework called ABCD Listing and Analysis framework is also effective for analysing both internal capabilities and external environmental opportunities of a multinational company. The following table 2 lists the possible frameworks to be used in the international business analysis along with the type of analysis and the focuses of such analysis process.

Table 2: Various frameworks used to analysis international business decisions along with their inventors and focuses on analysis

\begin{tabular}{|l|l|l|l|}
\hline S. No. & $\begin{array}{l}\text { Analysis } \\
\text { Framework }\end{array}$ & Type of Analysis & Focus of Analysis \\
\hline 1 & $\begin{array}{l}\text { SWOT/SWOC } \\
\text { analysis [7] }\end{array}$ & $\begin{array}{l}\text { Internal capabilities of firm in } \\
\text { International business }\end{array}$ & $\begin{array}{l}\text { Strength, Weakness, Opportunities, } \\
\text { and Threats/Challenges. }\end{array}$ \\
\hline
\end{tabular}




\begin{tabular}{|c|c|c|c|}
\hline & & performance & \\
\hline 2 & $\begin{array}{l}\text { PEST/PESTEL } \\
\text { analysis [8] }\end{array}$ & $\begin{array}{l}\text { External opportunities of the } \\
\text { firm in International business } \\
\text { performance }\end{array}$ & $\begin{array}{l}\text { Political, Economic, Sociological, } \\
\text { Technological, Legal, \& } \\
\text { Environmental analysis. }\end{array}$ \\
\hline 3 & $\begin{array}{l}\text { Six thinking hat } \\
\text { analysis [9] }\end{array}$ & $\begin{array}{l}\text { Both internal capabilities and } \\
\text { external opportunities for } \\
\text { international business decisions }\end{array}$ & $\begin{array}{l}\text { Managing Blue, Information White, } \\
\text { Emotions Red, Discernment Black, } \\
\text { Optimistic response Yellow, } \\
\text { Creativity Green. }\end{array}$ \\
\hline 4 & $\begin{array}{l}\text { McKinsey 7-S } \\
\text { framework [10] }\end{array}$ & $\begin{array}{l}\text { Internal capabilities of firm in } \\
\text { International business } \\
\text { performance }\end{array}$ & $\begin{array}{l}\text { Strategy, Structure, system, Shared } \\
\text { values, Skills, Style, and Staff. }\end{array}$ \\
\hline 5 & $\begin{array}{l}\text { Balanced } \\
\text { scorecard } \\
{[11]}\end{array}$ & $\begin{array}{l}\text { Studying firms ability to make } \\
\text { effective decisions from both } \\
\text { internal and external } \\
\text { perspective }\end{array}$ & $\begin{array}{l}\text { A management technique designed to } \\
\text { provide a view of an organization } \\
\text { from both internal and external } \\
\text { perspective. }\end{array}$ \\
\hline 6 & $\begin{array}{l}\text { Porter's Five } \\
\text { Forces analysis } \\
\text { [12] }\end{array}$ & $\begin{array}{l}\text { External challenges of the firm } \\
\text { in International business } \\
\text { decisions }\end{array}$ & $\begin{array}{l}\text { Five competitive forces on business } \\
\text { performance including threat of new } \\
\text { entrants, threat of substitutes, } \\
\text { bargaining power of customers, } \\
\text { bargaining power of suppliers, and } \\
\text { industry rivalry. }\end{array}$ \\
\hline 7 & $\begin{array}{l}\text { BCG's Growth } \\
\text { share matrix [13] }\end{array}$ & $\begin{array}{l}\text { Useful in National and } \\
\text { international business } \\
\text { performance study }\end{array}$ & $\begin{array}{l}\text { To rank the business units (or } \\
\text { products) on the basis of their } \\
\text { relative market shares and growth } \\
\text { rates into four categories as Cash } \\
\text { cows, Dogs, Question marks, and } \\
\text { Stars. }\end{array}$ \\
\hline 8 & $\begin{array}{l}\text { Value Chain } \\
\text { analysis [14] }\end{array}$ & $\begin{array}{l}\text { Internal capability of a firm to } \\
\text { decide on international } \\
\text { business }\end{array}$ & Primary and Support activities. \\
\hline 9 & Delta Model [15] & $\begin{array}{l}\text { Business performance } \\
\text { improvement in international } \\
\text { business }\end{array}$ & $\begin{array}{l}\text { Total customer solution, System lock- } \\
\text { in, Best product. }\end{array}$ \\
\hline 10 & $\begin{array}{l}\text { Resource Based } \\
\text { View Analysis } \\
\text { [16] }\end{array}$ & $\begin{array}{l}\text { Internal capability of a firm to } \\
\text { decide on international } \\
\text { business }\end{array}$ & $\begin{array}{l}\text { Tangible resources, Intangible } \\
\text { resources, and organizational } \\
\text { capabilities. }\end{array}$ \\
\hline 11 & $\begin{array}{l}\text { Core competency } \\
\text { analysis [17] }\end{array}$ & $\begin{array}{l}\text { Internal capability of a firm to } \\
\text { decide on international } \\
\text { business }\end{array}$ & $\begin{array}{l}\text { Organization's collective learning, } \\
\text { particularly of how to coordinate } \\
\text { diverse production skills and integrate } \\
\text { multiple technologies. }\end{array}$ \\
\hline 12 & $\begin{array}{l}\text { Heptalysis } \\
\text { Analysis [18] }\end{array}$ & $\begin{array}{l}\text { External opportunities of a firm } \\
\text { based on demand to enter } \\
\text { international business }\end{array}$ & $\begin{array}{l}\text { Market opportunity, Product/solution, } \\
\text { Execution plan, Financial engine, } \\
\text { Human capital, Potential return, and } \\
\text { Margin of safety. }\end{array}$ \\
\hline 13 & $\begin{array}{l}\text { MOST /VMOST } \\
\text { analysis [19] }\end{array}$ & $\begin{array}{l}\text { Not effective for international } \\
\text { business decision analysis }\end{array}$ & $\begin{array}{l}\text { Vision/Mission, Objectives, } \\
\text { Strategies, and Tactical. }\end{array}$ \\
\hline 14 & $\begin{array}{l}\text { CATWOE } \\
\text { analysis [20] }\end{array}$ & $\begin{array}{l}\text { External opportunities of a firm } \\
\text { based on opportunities to enter } \\
\text { international business }\end{array}$ & $\begin{array}{l}\text { Customers, Actors, Transformation } \\
\text { process, World view, Owner, } \\
\text { Environmental constraints. }\end{array}$ \\
\hline 15 & VPEC-T analysis & Not effective for international & Values, Policies, Events, Content, and \\
\hline
\end{tabular}

P. S. Aithal, (2017); www.srinivaspublication.com 


\begin{tabular}{|l|l|l|l|}
\hline & {$[21]$} & business decision analysis & Trust. \\
\hline 16 & $\begin{array}{l}\text { ICDT Model for } \\
\text { E-business [22] }\end{array}$ & $\begin{array}{l}\text { Not effective for international } \\
\text { business decision analysis }\end{array}$ & $\begin{array}{l}\text { Segmentation of the virtual 'market- } \\
\text { space' into four distinct areas: } \\
\text { Information Space, Communication } \\
\text { Space, Distribution Space, \& } \\
\text { Transaction Space. }\end{array}$ \\
\hline 17 & $\begin{array}{l}\text { ABCD Analysis } \\
{[23]}\end{array}$ & $\begin{array}{l}\text { Useful both internal } \\
\text { capabilities and external } \\
\text { opportunities for international } \\
\text { business decisions by using } \\
\text { required determinant issues }\end{array}$ & $\begin{array}{l}\text { Affecting Factors and Constituent } \\
\text { critical elements based on Key } \\
\text { attributes of various Determinant } \\
\text { issues of a concept, business model, } \\
\text { strategy, or a system, under four } \\
\text { constructs named as Advantages, } \\
\text { Benefits, Constraints, and } \\
\text { Disadvantages. }\end{array}$ \\
\hline
\end{tabular}

\section{FIRM’S INTERNAL ABILITY ANALYSIS USING SWOC FRAMEWORK :}

SWOC analysis can be used to evaluate the Strengths, Weaknesses, Opportunities, and Challenges involved in a multinational firm for carrying out international business. It involves specifying the objective of the multinational company and identifying the external and internal environmental factors which are favourable and unfavourable to realise that objective. The SWOC analysis gives information that is helpful in matching the firm's internal resources and capabilities to compete in the international business scenario [24-26].

\section{The SWOC Matrix}

A multinational firm should consider its strength correspondingly identify its upcoming opportunities. In such cases, the firm can overcome its weakness by identifying and preparing itself to face the challenges. To identify strategies to account the SWOC profile, a table of these factors in the form of a matrix called SWOC matrix model can be constructed.

\begin{tabular}{|l|l|l|l|}
\hline \multicolumn{2}{|c|}{} & \multicolumn{2}{|l|}{ Internal Analysis } \\
\cline { 3 - 4 } & Strengths & Weaknesses \\
\hline \multirow{2}{*}{ External Analysis } & Opportunities & S-O factors & W-O factors \\
\cline { 2 - 4 } & Challenges & S-C factors & W-C factors \\
\hline
\end{tabular}

Fig. 1: SWOC Matrix Model

$S-O$ factors pursue opportunities related to the MNC's strengths.

$\mathrm{W}$-O factors overcome weaknesses in the process of encashing opportunities.

$S-C$ factors determine the strengths of the MNC to face external challenges.

W-C factors suggest a defensive plan to avoid MNC's weaknesses and its negative consequences while fighting with external challenges.

(1) Strengths:

In international business, the analyser should identify the strengths of an MNC in terms of its resources and capabilities that can be used as a basis for developing a competitive advantage or monopoly strategies as core competency. Examples of such strengths include: arranging finance, patents based monopoly, leading \& self-motivated human resources, strong brand names, good reputation among customers, cost advantages from proprietary know-how, exclusive access to highgrade natural resources, favorable access to distribution networks etc. The strength of the multinational company can be analysed from its internal resources and capabilities to identify and perform international business in different countries as well as from its external strategies to identify and encash opportunities. 


\section{(2) Weaknesses:}

The absence of certain strengths for carrying out international business may be viewed as a weakness. For example, each of the following may be considered as weaknesses: inability of arranging finance for international expansion, lack of patent protection, a weak brand name, poor reputation among customers, high cost structure, unskilled and unmotivated human resources at operational and executive level, lack of access to the best natural resources, un-optimized usage of technology, lack of access to key distribution channels. In some cases, a weakness may be the flip side of strength. Sometimes, underutilized strength may become a weakness.

\section{(3) Opportunities:}

In international business analysis, opportunities are mainly dealt with the external environment and reveal certain new opportunities for profit and growth. Some examples of such opportunities in a given country include an unfulfilled customer need, arrival of new technologies, loosening of regulations, removal of international trade barriers, low investment cost, low competition or monopoly business opportunity, availability of skilled and competitive human resources etc.

\section{(4) Challenges:}

Changes in the external environmental also may present challenges to the firm. Some examples of such challenges include shifts in consumer tastes away from the firm's products, emergence of substitute products, new regulations, and increased trade barriers.

\section{FIRMS EXTERNAL OPPORTUNITY ANAL YSIS USING PESTEL FRAMEWORK :}

PESTEL analysis is a framework used to analyse the macro-environment of a business. PESTEL analysis can be used to study opportunities and challenges in international business investment [27]. The major components of PESTEL analysis framework are discussed in this section in detail.

\section{(a) Political Environment:}

The political environment in which international business decisions are taken by a firm consists of three important elements, namely, the home country political environment, the host country political environment, and the global political environment. These political elements listed may have either direct or an indirect influence on international business decisions and may also have either favorable or hostile impact to the activities of the international firm. While making a decision on the international investment, the business managers would prefer a political environment that was fully supportive of the interests of business.

1. Home Country Political Environment - As per the characteristics of an ideal world model, the home country/domestic politics will not affect a firm's international activities and decisions. But in reality, due to changes in political conditions and changes in governing political parties, the Country policy and State government policies towards accepting the FDI and subsidiaries of multinational companies are changing with time. Further, they may have far-reaching consequences for company's activities. In case of certain products categories, such as frontier military and nuclear technology, and scientific innovations with possible military applications, home country political environment play an important role in firms decision making process. The export of such Products may either be banned completely or subject to export control by the Home country government through enhanced tariffs, or fixing quotas, or limiting FDI flow etc. In another example, the domestic firms that continue to invest and manufacture abroad ignoring their home country are often accused for not contributing to solve domestic unemployment problems and hence may get political pressure from the home country governments. Finally, the international business decisions of a firm may be criticized by its home country government if these business decisions generate an international outcry by various stakeholders.

2. Host Country Political Environment - The host country policies governing the business decisions of foreign firms can range from the welcoming and supportive to the outright hostile. The political atmosphere tends to be hospitable where both perceived and actual benefits of hosting foreign firms outweigh their costs. The host country may develop its policies for easy FDI money transfer, and simplifying the permissions for construction of manufacturing facilities, which create employment opportunities in the host country and create other social benefits in the host market as well as from 
labour organisations. Sometimes, if the foreign firms contribute little or nothing to the well being of the nation and its society, then this may create unacceptable hostile behaviour from the business community and labour organisations. In extreme cases, this may lead to either nationalisation or the expropriation of the assets of foreign firms from the host country government and create a black dot on international investment decisions of the firms. Similarly, a breach of a stipulated code of conduct by international firms in a host country market may attract penalties and severe punishments.

3. Global Political Environment - This includes combined political situations of the home, host and third countries. The political atmosphere in a third country can have a major impact on the activities of international firms in ways that may not be immediately apparent. Depending on the form of integration between member countries like Custom Union, or Common Market, or Economic Union, or Economic Integration, and Multilateral agreements between international organisations such as GATT, the United Nations, and the Commonwealth may exercise necessary checks and balances on international firms.

\section{(b) The Economic Environment:}

The economic environment is the most important parameter for international business decisions. In fact, the economic environment is the potential for the success of the international trade. The economic environment parameter covers both domestic or national and international or global. There are a number of general and useful indicators that are needed for assessing an economic environment in which most of the multinational companies operate. These indicators are population, per capita income, income distribution, and type of the economy of both home and host countries.

1. Population - Market size is generally a function of population and purchasing power propensity. As a general rule, the larger the population, the better is the market. Although it is rational to suggest that there is no correlation between population size and sales potential, it is the assumption that population is the primary indicator of the size of any market. Many product categories like food, drugs, electronics, and other basic but essential products get greater demand if the population is higher. Thus, because of the size of the population, China and India are usually considered as important markets for many international firms. Geographical distribution of population should also be taken into consideration. In many countries, urban centres are densely populated compared to their rural counterparts. The pattern of shopping in cities varies considerably compared to villages. Demographic parameters like age, education, and composition of the population should also be taken into account while taking the international business decisions.

2. Per capita Income - Per capita distribution of income is also a major factor while assessing the economic environment. Per capita income measures the performance of an economy in relation to the size of the population. Based on per capita income, country economies have been classified into four types as High-income economies, Upper-middle-income economies, Lower-middle-income economies, and Low-income economies. However, it is misleading to rely completely on per capita income in evaluating a country's marketing potential and ability in supporting international firms.

3. Income Distribution - International firms must take into account income distribution among the people instead of dependent on per capita income alone. This is due to the reason that for certain products such as non-basic luxury items, only a part of the population show interest in purchasing. In some of the poor countries where wealth is concentrated in the hands of a tiny minority of the population, the demand is comparable to the pattern of demand in fairly affluent countries.

4. Type of the Economy - The economic condition of the country and the nature of the people in spending decisions also affect the opportunity and success of the firms in investing in a country. If the nature of the people in a country is on lavishly spending out of the earned money instead of long time savings for future requirements, then there is a prosperous atmosphere for the international investors. Thus nature of people in their spending and their ability of earning in all kinds of economies like, High-income economies, Upper-middle-income economies, Lower-middle-income economies, and even in Low-income economies attract potential international investments.

(c) Socio-Cultural Environment :

Socio-Culture deals with a set of values, beliefs, rules, and institutions held by a specific group of people in the society. With increasing globalisation, it must be emphasized that lack of understanding 
of the significance of socio-culture in deciding consumer attitudes, lifestyle and behaviour may be catastrophic for the multinational firm [28-31].

When multinational firms take a decision to invest and move to different countries, they are confronted with a new set of values and lifestyles, which is quite different from those they are familiar with in their home country. In such cases, the performance of the firm in the international arena partly depends on how well the marketing mix elements fit into the culture of host market. Culture is one of the most important determinants of consumer behaviour. It influences the process of decision-making in the day-to-day buying habits of consumers. Culture is central to how products and the process of marketing are viewed. Thus, there is a need for cross-cultural understanding between the countries because of their significant differences in attitude, belief, motivation, perception, and lifestyle. The most important task of the international marketer is to identify relevant similarities and differences among target markets. The socio-cultural environment affects all aspects of marketing. It affects the consumer perception of products, distribution, pricing, and communications policies and strategies. For example,

1. Product: The usefulness and the utility of a single product may differ considerably from country to country. Fast food such as Kentucky Fried Chicken, McDonald's beef burgers have higher sales in modern societies than in traditional societies. Similarly, the tradition based sales of some products are different at different time and at different places of a country and of many different countries.

2. Pricing: Products manufactured from certain locations of the world such as Europe, Australia, and the United States command premium prices along with higher demand in developing countries due to the fact that they possess higher perceived quality than locally manufactured products. Thus, products with labels 'Made in England', 'Made in Japan' facilitate more acceptability from the consumers compared to made in India, made in Thailand, and Made in China. International business decision maker should consider such behaviour of the consumers and plan appropriate strategy to counter it.

3. Promotion: The product promotion and advertisement strategy used in one country need not be acceptable or successful in all international markets due to changes in culture, tradition, tastes, and perception of people. It is known that the consumer acceptance and behaviour depends on their feelings while purchasing and using a product and depends on their belief which in turn depends on their environmental social-culture and tradition. Thus in the face of globalization, cross-cultural understanding is absolutely essential for the success of international business. When a firm enters into the international business market, the decision on localizing business policies, practices, and strategies can help managers to succeed.

(d) Technological Environment :

Technology and its transfer have become the key factors in the international business decisions. The technology is changing at a greater speed due to continuous R\&D efforts of organizations in every industry and industry sectors of major countries. The effect of technology on international business practices and decisions had a major role and perhaps has continued effect due to many anticipated breakthrough technologies during $21^{\text {st }}$ century [32]. It is the technology, which gives the greatest competitive advantage to the multinational firms to expand their business to many countries against the competition and resistance from local competitor firms. Technological leadership is achieved by many multinational companies through continuous innovation, research, and development by reserving a considerable part of their annual budget due to the reason that technological innovations are very costly. Thus, the costs of successful innovations are recovered by internationalization of the technical know-how. In the present scenario, certainly, no country can remain isolated from the impact of technological revolution and it is technology that rather diminishes local and regional differences. Thus, technological evolution and the growing importance of technology in many countries encourage the international business firms to decide on their strategies on the globalization of markets.

The noticeable effect on international business decisions due to changes in technology got further fuel after 1990 due to world-wide spreading of Internet technology, Information Communication Technology, High-tech transportation Technology, Automation \& robotic Technology, etc. Many anticipated breakthrough technologies during $21^{\text {st }}$ century including Nanotechnology, Spacetechnology, Biotechnology, Optical technology, Virtual reality, Artificial intelligence \& IOT etc. are 
also expected to affect the existing International business model drastically.

(e) Ecological Environment :

Ecological and geographical environmental factors, such as natural resource endowments, weather and climatic conditions, topographical factors, locational aspects in the global context, airport \& waterport facilities, etc., are all relevant to international business. Differences in geographical conditions between markets may sometimes call for changes in the marketing mix. Geographical and ecological factors also influence the location of certain industries. For example, industries with high material index tend to be located near the raw material sources. Climatic and weather conditions affect the location of certain industries like the cotton textile industry. Topographical factors may, affect the demand pattern. For example, in hilly areas with a difficult terrain, jeeps may be in greater demand than cars.

Ecological factors have recently assumed great importance. The depletion of natural resources, environmental pollution and the disturbance of the ecological balance has caused great concern. Government policies aimed at the preservation of environmental purity and ecological balance, conservation of non-replenishale resources, etc., have resulted in additional responsibilities and problems for international business, and some of these have the effect of increasing the cost of production and marketing. Location of production system at close vicinity to both supply of raw materials and the high demand market at premier price is always plus point.

\section{(f) The Legal Environment :}

The legal environment in any country for international investment and market relates to the laws and regulations governing the investment decisions and conduct of business activities in that market. It may be expressed as a function of the socio-cultural, political, and ideological orientation of a country, and the perceived role of multinational companies in a nation's economy and development. Thus, every sovereign nation has a legal system that reflects its socio-cultural and political values and beliefs. Multinational firms have to deal with varied and sometimes complex legal systems across the world while taking international business decisions. The international legal environment has three aspects: home country laws, host country laws, and international laws.

(1) Home Country Laws - Home country laws deal with the conduct of the firm in the domestic market and trade with third countries. These laws and regulations do not discriminate between domestic and international operators as they are designed to protect the domestic consumers, national interest, and security. However, for the international operators, there may be some additional controls on exporting to third countries. The export of high technology products with military applications like nuclear weapons and chemical weapons fall into this category and is normally controlled by individual country laws to ensure that they do not get into the wrong hands.

(2) Host Country Laws - Multinational firms have to deal a number of regulations in host countries. The important controls include investment regulations, tariffs and duties, antidumping regulations and the protection policies of local industries. Many developing countries have designed many laws for foreign firms to either exclude them from competing with domestic firms in certain sectors or their involvement in many industry sectors is severely restricted. Tariffs and duties are used to discourage importation of non-essential products in order to conserve foreign exchange and maintain a favourable balance of trade.

(3) International Laws - International law is the collection of treaties, conventions and agreements between nations, which have more or less the force of law. They are usually multilateral among many nations. National parliaments normally ratify these treaties and conventions to provide them with the force of law and they have considerable international implications. International laws are particularly relevant in areas relating to patents and trademark protective' and piracy laws, UN resolutions, multilateral trade agreements, and codes of conduct for multinational firms. Registered intellectual properties and unique right (patents) of inventions are protected by international law under the auspices of the WIPO (World Intellectual Property Organization). Infringements are vigorously contested by patent owners. 


\section{FIRM'S INTERNAL PERFORMANCE AND EXTERNAL OPPORTUNITY ANALYSIS USING ABCD LISTING :}

ABCD listing and analysis framework is recently introduced a general technique to analyse any system, strategy, concept, technology, material, business model etc. by considering various frame of reference called determinant issues. In this technique, for every determinant issue the analyser has to choose some key attributes and for every key attribute, the affecting factors have to be determined under four constructs called Advantages, Benefits, Constraints, and Disadvantages. Since various affecting factors of the system or model are systematically identified under different determinant issues, the framework is also named as factor analysis method. Further, this framework allows to identify constituent elements for each affecting factor and based on weightage score, the analyser can identify critical constituent elements. The systematic analysis of International business and its environments using $A B C D$ analysisng framework is under progress and will be published elsewhere. Here, we have used ABCD listing method (figure 2) which is the qualitative part of the technique to analyse the International Business model of a multinational firm.

\subsection{Advantages of International Business Investment :}

As per the procedure, the advantages under five determinant issues (organizational issue, Host country issue, Home country issue, Customer issue, and global issue) are listed below :

(1) From organizational point of view :

- Opportunity for expansion of business

- Production across the globe

- Opportunity to get low cost location and raw materials

- Improved quality due to access of better technology

- Access to skilled labours in other countries

- Expansion of business different countries

- Product flexibility

- Access to low cost investment fund

(2) From Host Country point of view :

- Increased investment from foreign companies

- Quality products/services to local people at competitive price

- Access of latest technology to the country

- Increased wages for labours from Multinational companies

- Foreign currency investment in the country

- Higher tax and tariff collection from host country government

(3) From Home Country point of view :

- Foreign earning opportunity for local companies

- Opportunity to invest in different countries for local firms

- Learning new methods in international locations and transferring it to home country

- Monopoly products and services having patents in the country find huge market

(4) From the Customer point of view :

- Access to quality standard products

- Competition between MNC's and local firms leads to quick product delivery

- Respect to consumer laws

(5) From the Global point of view :

- Access to global technology

- Access to global talents

- Access to global investments

- Cost-effective manufacturing opportunity

- Access to global market where prices are highest

- Access to international strategic alliances 


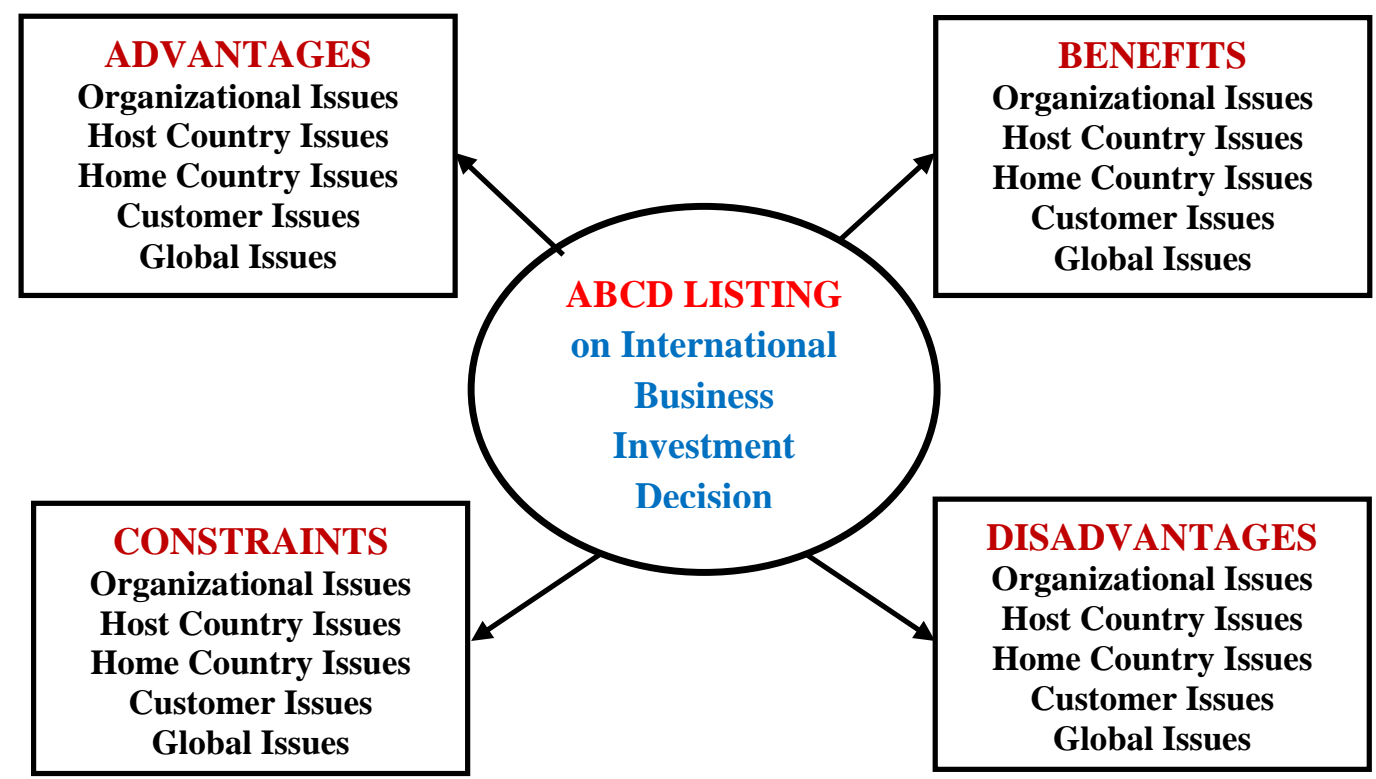

Figure 2 : Determinant issues in ABCD Listing of International business investment decisions

7.2. Benefits of International Business Investment :

(1) From organizational point of view :

- Increased sales and hence profit

- Access low cost quality resources

- Decreased cost of doing business

- Enhanced profit due to improved quality and features of products

- Improved efficiency of production and service along with decreased wastage

- Minimized competitive risk

- Decreased business cost due to low cost finance

(2) From Host Country point of view :

- Enhanced employment creation

- Challenge to local firms to be competitive

- Standardized products to the consumer at competitive rate

- Improvement in per capita income and GDP

- Improved balance of payment

- Increased country income

(3) From Home Country point of view :

- Increased profit for local firms which become multinational

- Financial stability to local firms which do business in many countries

- New effective methods of production from other countries to improve the efficiency

- Monopoly products of home country firms make huge profit in foreign countries

(4) From the Customer point of view :

- Access to quality standard global products at competitive price

- Competition between MNC's and local firms leads low price for quality products

- Better after sales support

(5) From the Global point of view :

- Access to global technology leads to high tech products \& services

- Access to global talents leads to better product design and features

- Access to global investments leads to infrastructure, employment, corporate social responsibility etc.

- Cost effective manufacturing opportunity leads to proper utilization of raw materials

- Local firms get Access to global market where prices are highest leads to enhanced return 
- Access to international strategic alliances leads to improvement in business practices

7.3. Constraints of International Business Investment :

(1) From organizational point of view :

- High investment

- Investment risk

- International permissions

- Home country international investment policies

- Host country FDI policies

- Risk of strategic alliance

- Managing business in new culture, language, and currency

- Technology risk

- Difficulties in monitoring international business

(2) From Host Country point of view :

- Threat to local firms

- Local technology transfer to other country without any benefit

- Controlling activities of MNC's in the country through suitable law

- Environmental degradation control

- Constraint on providing skill based employees as per MNC's requirement

- Hike of local land price

(3) From Home Country point of view :

- Large amount of money transfer to other countries

- Home country technology transfer to other countries

- Brain drain to other countries

- Export of raw materials may increase demand

(4) From Customer point of view :

- Increase in price for standard products

- Monopoly sellers of products due to local firms inability to compete

(5) From Global point of view :

- Damage to local tradition and culture

- Minimization of country based differences in human lifestyle

7.4. Disadvantages of International Business Investment :

(1) From organizational point of view :

- Currency fluctuation based losses

- Risk of loss due to High investment \& uncertainty in business environment

- High tariff for international companies

- Loss of proprietary technology

- Break of alliance in foreign country

- Competition from local firms

(2) From Host Country point of view :

- High Bargain power of MNC's

- Closure of local firms due to their inability to compete.

- Loss of Employment of local people

- Environmental degradation and its consequence

- Influencing on country politics

(3) From Home Country point of view :

- Products prices may increase

- Increased demand for some raw material increases their price in home country

(4) From Customer point of view :

- Addiction to foreign products

- Discouraging local product 
- Complex consumer protection law

(5) From Global point of view :

- Danger of global culture which destroy local traditions and beliefs

- Environmental damage

- Trade unions are not recognized

\section{CONCLUSION :}

International business, being positive sum game, where all the stake holders are expected to be winners, a systematic analysis using identified frameworks are essential to make successful decisions. In this paper, various business analysing frameworks used to analyse the business system and strategy used by many international firms and the environmental factors affecting their business are discussed with an intention have an insight on major environmental factors of a firm which affects the international business decisions. Various frameworks used to analyse International business Decisions of a firm based on its internal and external environments are discussed by studying their operational environment, business environment, and corporate environment. Some of the important frameworks/techniques in terms of their discussion parameters, various variables used in the analysis, determinant issues, and implications on decisions related to new investments and continuing the existing business in different countries are discussed further. The use of SWOC framework to identify the strength, weakness, opportunities, and challenges of a firm in its international business objectives are also studied. Finally, the use ABCD listing methodology to identify the advantages, benefits, constraints, and disadvantages of these identified frameworks to analyse international business strategies and environmental analysis frameworks are discussed and listed under five determinant issues which include organizational point of view, Host Country point of view, Home Country point of view, Customer point of view, and Global point of view.

\section{REFERENCES :}

[1] Welch, L. S., \& Luostarinen, R. (1988). Internationalization: Evolution of a concept. Journal of general management, 14(2), 34-55.

[2] Hubbard, G. (2009). Measuring organizational performance: beyond the triple bottom line. Business strategy and the environment, 18(3), 177-191.

[3] Peng, M. W., Wang, D. Y., \& Jiang, Y. (2008). An institution-based view of international business strategy: A focus on emerging economies. Journal of international business studies, 39(5), 920936.

[4] Terjesen, S., Hessels, J., \& Li, D. (2016). Comparative international entrepreneurship: A review and research agenda. Journal of Management, 42(1), 299-344.

[5] Francioni, B., Musso, F., \& Cioppi, M. (2015). Decision-maker characteristics and international decisions for SMEs. Management Decision, 53(10), 2226-2249.

[6] Aithal, P. S. (2017). ABCD Analysis as Research Methodology in Company Case Studies. International Journal of Management, Technology, and Social Sciences (IJMTS), 2(2), 40-54. DOI: http://dx.doi.org/10.5281/zenodo.891621.

[7] Humphrey, A. S. (2005). SWOT analysis. Long Range Planning, 30, 46-52.

[8] Aguilar, Francis J. (1967), Scanning the business environment. New York, Macmillan. pp. 1-237.

[9] De Bono, E., \& De Bono, E. (1999). Six thinking hats (Vol. 192). New York: Back Bay Books.

[10] Waterman, R. H., Peters, T. J., \& Phillips, J. R. (1980). Structure is not organization. Business horizons, 23(3), 14-26.

[11] Schneiderman, A. M. (1999). Why balanced scorecards fail. Journal of strategic performance measurement, 2(11). 
[12] Porter, M. E. (2008). The five competitive forces that shape strategy. Harvard business review, 86(1), 25-40.

[13] Henderson, B. D. (1979). The product portfolio: growth share matrix of the Boston Consulting Group. The strategy process: Concepts, contexts, cases, 678-680.

[14] Porter, M. E., \& Millar, V. E. (1985). How information gives you competitive advantage.

[15] Hax, A. C., \& Wilde, D. L. (2003). The delta model-a new framework of strategy. Journal of Strategic Management Education, 1(1), 1-21.

[16] Barney, J. B. (2001). Resource-based theories of competitive advantage: A ten-year retrospective on the resource-based view. Journal of management, 27(6), 643-650.

[17] Prahalad, C. K., \& Hamel, G. (1997). The core competence of the corporation. En Foss, 235-56.

[18] Pejman Makhfi (2005). Heptalysis - The Venture Assessment Framework. Venture Choice, Inc. Retrieved 22/08/2017.

[19] Sondhi K. Rakesh (1999), Total Strategy. Airworthy publications International.

[20] Checkland, P. B., and Scholes, J. (1990). Soft Systems Methodology in Action, Wiley, New York.

[21] Hunt, David, Bacon, Liz (2009). VPEC-T: A Way to Bridge the Gap Between Business and IT. Enterprise Architecture Conference Europe 2009. Retrieved 2017-08-14.

[22] Angehrn, A. (1997). Designing mature Internet business strategies: the ICDT model. European Management Journal, 15(4), 361-369.

[23] Aithal, P. S., (2016). Study on ABCD Analysis Technique for Business Models, Business Strategies, Operating Concepts \& Business Systems. International Journal in Management and Social Science, 4(1), 98-115. DOI : http://doi.org/10.5281/zenodo.161137.

[24] Hill, T., \& Westbrook, R. (1997). SWOT analysis: it's time for a product recall. Long range planning, 30(1), 46-52.

[25] Bohari, A. M., Hin, C. W., \& Fuad, N. (2017). The competitiveness of halal food industry in Malaysia: A SWOT-ICT analysis. Geografia-Malaysian Journal of Society and Space, 9(1).

[26] Aithal, P. S. and Suresh Kumar, P. M. (2015). Applying SWOC Analysis to an Institution of Higher Education. International Journal of Management, IT and Engineering (IJMIE), 5(7), 231247. DOI : http://doi.org/10.5281/zenodo.163425.

[27] Issa, T., Chang, V., \& Issa, T. (2010). Sustainable business strategies and PESTEL framework. GSTF International Journal on Computing, 1(1), 73-80.

[28] Leung, K., Bhagat, R. S., Buchan, N. R., Erez, M., \& Gibson, C. B. (2005). Culture and international business: Recent advances and their implications for future research. Journal of international business studies, 36(4), 357-378.

[29] Søderberg, A. M., \& Holden, N. (2002). Rethinking cross cultural management in a globalizing business world. International Journal of Cross Cultural Management, 2(1), 103-121.

[30] Samaha, S. A., Beck, J. T., \& Palmatier, R. W. (2014). The role of culture in international relationship marketing. Journal of Marketing, 78(5), 78-98.

[31] López-Duarte, C., Vidal-Suárez, M. M., \& González-Díaz, B. (2016). International business and national culture: a literature review and research agenda. International Journal of Management Reviews, 18(4), 397-416.

[32] Aithal, P. S. \& Shubhrajyotsna Aithal, (2015). Managing Anticipated Breakthrough Technologies of 21st Century-A review. International Journal of Research \& Development in 
Technology and Management Sciences, 21(6), 112 - 133, DOI : http://doi.org/10.5281/zenodo.61617.

[33] Aithal, P. S., Shailashree, V. T., Suresh Kumar, P. M. (2015). A New ABCD Technique to Analyze Business Models \& Concepts. International Journal of Management, IT and Engineering (IJMIE), 5(4), 409 - 423. DOI : http://doi.org/10.5281/zenodo.61652.

[34] Reshma, Aithal, P S, Shailashree, V T, Sridhar Acharya, P. (2015). An Empirical study on working from home - A popular E-business model. International Journal of Advance and Innovative Research, 2(2 (I)), 12-18. DOI : http://doi.org/10.5281/zenodo.164429.

[35] Aithal, P. S., Shailashree, V. T., \& Suresh Kumar, P. M. (2015). Application of ABCD Analysis Model for Black Ocean Strategy. International Journal of Applied Research (IJAR), 1(10), 331337. DOI: http://doi.org/ 10.5281/zenodo.163424.

[36] Aithal, P. S., Shailashree, V. T., \& Suresh Kumar, P. M. (2016). ABCD analysis of Stage Model in Higher Education. International Journal of Management, IT and Engineering (IJMIE), 6(1), 11-24. DOI: http://doi.org/10.5 281/zenodo.154233.

[37] Aithal, P. S., Shailashree, V.T., \& Suresh Kumar, P. M. (2016). Analysis of NAAC Accreditation System using ABCD framework. International Journal of Management, IT and Engineering (IJMIE), 6(1), 30 - 44. DOI: http://doi.org/10.5281/zenodo.154272.

[38] Aithal, P. S., Shailashree, V. T., \& Suresh Kumar, P. M. (2016). Application of ABCD Analysis Framework on Private University System in India. International Journal of Management Sciences and Business Research (IJMSBR), 5(4), 159-170. DOI : http://doi.org/10.5281/zenodo.161111.

[39] Aithal, P. S., Shailashree, V. T., \& Suresh Kumar, P. M., (2016). The Study of New National Institutional Ranking System using ABCD Framework. International Journal of Current Research and Modern Education (IJCRME), 1(1), 389 - 402. DOI : http://doi.org/10.5281/zenodo.161077.

[40] Aithal, P. S., Shailashree, V. T. \& Suresh Kumar, P. M., (2016). Analysis of ABC Model of Annual Research Productivity using ABCD Framework. International Journal of Current Research and Modern Education (IJCRME), 1(1), 846-858. DOI : http://doi.org/10.5281/ zenodo.62022.

[41] Shubhrajyotsna Aithal, \& Aithal, P. S., (2016), ABCD analysis of Dye doped Polymers for Photonic Applications. IRA-International Journal of Applied Sciences, 4(3), 358-378. DOI : http://dx.doi.org/10.21013/jas.v4.n3.p1.

[42] Aithal, P. S. \& Suresh Kumar, P. M. (2016). CCE Approach through ABCD Analysis of 'Theory A' on Organizational Performance. International Journal of Current Research and Modern Education (IJCRME) 1(1), 169-185. DOI: http://dx.doi.org/10. 5281/zenodo.164704.

[43] Varun Shenoy, \& Aithal P. S., (2016). ABCD Analysis of On-line Campus Placement Model, IRA-International Journal of Management \& Social Sciences, 5(2), 227-244. DOI: http://dx.doi.org/10.21013/jmss.v5.n2.p3.

[44] Aithal, P. S., Shailashree V. T. \& Suresh Kumar P.M. (2016). Factors \& Elemental Analysis of Six Thinking Hats Technique using ABCD Framework. International Journal of Advanced Trends in Engineering and Technology (IJATET), 1(1), 85-95. DOI : http://doi.org/10.5281/zenodo.240259.

[45] Aithal, P. S. (2017). ABCD Analysis of Recently Announced New Research Indices. International Journal of Management, Technology, and Social Sciences (IJMTS), 2(1), 65-76. DOI: http://doi.org/10.5281/zenodo. 583644.

[46] Aithal, P. S. (2017). Factor Analysis based on ABCD Framework on Recently Announced New 
Research Indices, International Journal of Management, Technology, and Social Sciences (IJMTS), 1(1), 82-94. DOI: http://dx.doi.org/10.5281/zenodo.584105.

[47] Aithal P. S. and Varambally, K. V. M. (2006). Security Issues in Online Financial Transactions with Special Reference to Banking Industry. In Quality in Service Sector and Managerial Challenges, Allied Publisher Pvt. Ltd. 2006, ISBN: 81-7764-992-2, pp 103- 114.

[48] Aithal, P. S., \& Varambally, K. V. M. (2009). Mobile Business Technology and Business Proliferation of Banks - A futuristic Approach. Amity Business Review - an Indian Journal, 10(1), 9-25.

[49] Aithal, P. S., \& Shubhrajyotsna Aithal, (2015). A review on Anticipated Breakthrough Technologies of 21st Century. International Journal of Research \& Development in Technology and Management Sciences, 21(6), 112-133. DOI: http://doi.org/10.5281/zenodo. 61617.

[50] Aithal, P. S., \& Shubhrajyotsna Aithal, (2015). An Innovative Education Model to realize Ideal Education System. International Journal of Scientific Research and Management (IJSRM), 3(3), 2464 -2469. DOI: http://doi.org/10.5281/zenodo.61654.

[51] Sridhar Acharya, P. \& Aithal, P. S. (2016). Clean Energy for Poor - A Changing Scenario. International Journal of Advanced Trends in Engineering and Technology (IJATET), 1(1), 129133. DOI : http://doi.org/10.5281/zenodo.240287.

[52] Aithal, P. S., Shailashree V. T \& Suresh Kumar P. M., (2016). Analysis of ABC Model of Annual Research Productivity using ABCD Framework. International Journal of Current Research and Modern Education (IJCRME), 1(1), 846-858. DOI : http://doi.org/10.528 1/zenodo.62022.

[53] Aithal, P. S. \& Suresh Kumar, P. M. (2016). Opportunities and Challenges for Private Universities in India. International Journal of Management, IT and Engineering (IJMIE), 6(1), 88-113. DOI : http://doi.org/10.5281/zenodo. 161157.

[54] Sridhar Acharya, P. \& Aithal, P. S., (2016). Concepts of Ideal Electric Energy System for production, distribution and utilization. International Journal of Management, IT and Engineering (IJMIE), 6(1), 367-379. DOI : http://doi.org/10.5281/zenodo.161143.

[55] Padmanabha Shenoy, \& Aithal, P. S., (2016). A Study on History of Paper and possible Paper Free World. International Journal of Management, IT and Engineering (IJMIE), 6(1), 337-355. DOI : http://doi.org/10.5281/zenodo. 161141.

[56] Aithal, P.S., (2015). Comparative Study on MBA Programmes in Private \& Public Universities A case study of MBA programme plan of Srinivas University, International Journal of Management Sciences and Business Research (IJMSBR), 4(12), 106-122. DOI : http://doi.org/10.5281/zenodo.163884.

[57] Aithal P. S., \& Shubhrajyotsna Aithal (2016). Impact of On-line Education on Higher Education System. International Journal of Engineering Research and Modern Education (IJERME), 1(1), 225-235. DOI : http://doi.org/ 10.5281/zenodo.161113.

[58] Aithal P. S., and Suresh Kumar P. M., (2016). Analysis of Choice Based Credit System in Higher Education. International Journal of Engineering Research and Modern Education (IJERME), 1(1), 278-284. DOI : http://doi.org/ 10.5281/zenodo.161046.

[59] Varun Shenoy and Aithal P. S., (2016). Changing Approaches in Campus Placements - A new futuristic Model, International Journal of Scientific Research and Modern Education (IJSRME), 1(1), 766 - 776. DOI : http://doi.org /10.5281/zenodo.160966.

[60] Prithi Rao, and Aithal, P.S. (2016). Green Education Concepts \& Strategies in Higher Education Model, International Journal of Scientific Research and Modern Education (IJSRME), 1(1), 793802. DOI : http://doi.org/ 10.5281/zenodo.160877. 
[61] Aithal, P. S. \& Shubhrajyotsna Aithal (2016). Ekalavya Model of Higher Education - an Innovation of IBM's Big Data University. International Journal of Current Research and Modern Education (IJCRME), 1(2), 190-205. DOI: http://dx.doi.org/10.5281/ZENODO.198704.

[62] Aithal, P. S. \& Shubhrajyotsna Aithal, (2016). A New Model for Commercialization of Nanotechnology Products and Services. International Journal of Computational Research and Development, 1(1), 84-93. DOI : http://doi.org/10.5281/zenodo.163536.

[63] Aithal, P. S., (2017). ABCD Analysis as Research Methodology in Company Case Studies. International Journal of Management, Technology, and Social Sciences (IJMTS), 2(2), 40-54. DOI: $\underline{\text { http://dx.doi.org/10.5281/zenodo.891621. }}$

[64] Architha Aithal, and Aithal, P. S., (2017). ABCD Analysis of Task Shifting - An optimum Alternative Solution to Professional Healthcare Personnel Shortage. International Journal of Health Sciences and Pharmacy (IJHSP), 1(2), 36-51.

DOI: http://dx.doi.org/10.5281/zenodo.1038975. 